\title{
A Centrally Acting, Anxiolytic Angiotensin II AT, Receptor Antagonist Prevents the Isolation Stress-Induced Decrease in Cortical CRF, Receptor and Benzodiazepine Binding
}

\author{
Juan M Saavedra*,', Ines Armando', Claudia Bregonzio', Augusto Juorio', Miroslava Macova', Jaroslav Pavel' \\ and Enrique Sanchez-Lemus' \\ 'Section on Pharmacology, National Institute of Mental Health, National Institutes of Health, Bethesda, MD, USA
}

\begin{abstract}
Long-term pretreatment with an angiotensin II AT, antagonist blocks angiotensin II effects in brain and peripheral organs and abolishes the sympathoadrenal and hypothalamic-pituitary-adrenal responses to isolation stress. We determined whether AT, receptors were also important for the stress response of higher regulatory centers. We studied angiotensin II and corticotropin-releasing factor (CRF) receptors and benzodiazepine binding sites in brains of Wistar Hannover rats. Animals were pretreated for 13 days with vehicle or a central and peripheral AT, antagonist (candesartan, $0.5 \mathrm{mg} / \mathrm{kg} /$ day) via osmotic minipumps followed by $24 \mathrm{~h}$ of isolation in metabolic cages, or kept grouped throughout the study (grouped controls). In another study, we determined the influence of a similar treatment with candesartan on performance in an elevated plus-maze. AT, receptor blockade prevented the isolation-induced increase in brain $A T$, receptors and decrease in $A T_{2}$ binding in the locus coeruleus. $A T_{1}$ receptor antagonism also prevented the increase in tyrosine hydroxylase mRNA in the locus coeruleus. Pretreatment with the AT, receptor antagonist completely prevented the decrease in cortical

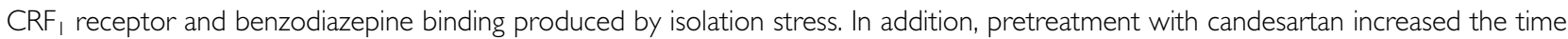
spent in and the number of entries to open arms of the elevated plus-maze, measure of decreased anxiety. Our results implicate a modulation of upstream neurotransmission processes regulating cortical $C_{2} F_{1}$ receptors and the GABA $\mathrm{A}_{\mathrm{A}}$ complex as molecular mechanisms responsible for the anti-anxiety effect of centrally acting $A T$, receptor antagonists. We propose that $A T$, receptor antagonists can be considered as compounds with possible therapeutic anti-stress and anti-anxiety properties.
\end{abstract}

Neuropsychopharmacology (2006) 3 I, I | 23- | | 34. doi: I 0. I038/sj.npp. 130092 I; published online 5 October 2005

Keywords: $\mathrm{GABA}_{\mathrm{A}}$ complex; anxiety; isolation; tyrosine hydroxylase; locus coeruleus; angiotensin receptor types

\section{INTRODUCTION}

Angiotensin II (Ang II) contributes to regulate the sympathetic and neuroendocrine systems and it is an important stress hormone (Saavedra, 1992; Phillips, 1997). There are two types of Ang II receptors, the $\mathrm{AT}_{1}$ and $\mathrm{AT}_{2}$ types. The well-known physiological actions of Ang II are dependent on $\mathrm{AT}_{1}$ receptor stimulation; the physiological role of $\mathrm{AT}_{2}$ receptors is controversial (Saavedra, 1999; De Gasparo et al, 2000). $\mathrm{AT}_{1}$ receptors are present throughout the hypothalamic-pituitary-adrenal axis (HPA), highly concentrated in key areas regulating the stress response (Tsutsumi and Saavedra, 1991a,b; Jöhren et al,

\footnotetext{
*Correspondence: Dr JM Saavedra, Section on Pharmacology, DIRP, National Institute of Mental Health, National Institutes of Health, DHHS, 10 Center Drive, MSC 1514, Building 10, Room 2D-57, Bethesda, MD 20892, USA, Tel: + I 301 496 0160, Fax: + I 301402 0337, E-mail: Saavedr@@mail.nih.gov

Received 17 May 2005; revised 29 July 2005; accepted 25 August 2005 Online publication: I September 2005 at http://wmw.acnp.org/citations/ Npp090 10505033 I/default.pdf
}

1995; Israel et al, 1995). During stress, there is increased renin production and higher circulating and brain Ang II (Xang et al, 1993; Yang et al, 1996), leading to enhanced stimulation of peripheral and brain $\mathrm{AT}_{1}$ receptors. In addition, isolation (Armando et al, 2001; present results) and restraint (Castrén and Saavedra, 1988; Leong et al, 2002; Aguilera et al, 1995a) increased $\mathrm{AT}_{1}$ receptor expression in brain areas inside and outside the bloodbrain barrier and related to the control of the hormonal and sympathoadrenal responses to stress, probably as a result of stimulation of glucocorticoid response elements in the receptor promoter region by increased corticosterone levels (Guo et al, 1995). This indicates that stress is likely to increase the effects of brain-generated Ang II and those of circulating Ang II in the brain (Saavedra, 1992).

Stress increases the $\mathrm{AT}_{1}$ receptor expression in the parvocellular hypothalamic paraventricular nucleus (PVN), the site of corticotropin-releasing factor (CRF) formation (Castrén and Saavedra, 1988; Aguilera et al, 1995a; Jezova et al, 1998; Leong et al, 2002), and stimulation 
of $\mathrm{AT}_{1}$ receptors in the $\mathrm{PVN}$ by Ang II increases CRF production (Sumitomo et al, 1991; Aguilera et al, 1995b). $\mathrm{AT}_{1}$ receptors from the $\mathrm{PVN}$ are transported to the median eminence through axons coexpressing CRF (Oldfield et al, 2001). Released into the hypothalamic portal system, CRF increases pituitary ACTH. These findings indicate that upregulation of $\mathrm{AT}_{1}$ receptors in the $\mathrm{PVN}$ is a major factor modulating the increased $\mathrm{CRF}$ production, which is followed by a cascade of stimulated ACTH release and increased adrenal corticoid secretion, the hallmark of the stress reaction.

Because $\mathrm{AT}_{1}$ receptor stimulation enhanced CRF formation and release during stress, it was reasonable to ask whether a limitation of the Ang II tone maintained over time, such as that resulting from long-term antagonism of $\mathrm{AT}_{1}$ receptors, could decrease or prevent the hormonal response to stress. We demonstrated that long-term treatment with candesartan, an insurmountable $\mathrm{AT}_{1}$ antagonist that, when administered peripherally, readily inhibits not only peripheral but also central $\mathrm{AT}_{1}$ receptors (Nishimura et al, 2000), abolished the HPA axis and sympathoadrenal response to isolation in rats (Armando et al, 2001). Isolation is a clinically relevant model of emotional stress resulting from the restriction from freely regulating exposure to novel surroundings and access to familiar territory. In addition, candesartan pretreatment prevented the gastric ulceration produced by cold-restraint stress in rats (Bregonzio et al, 2003). This suggested that antagonism of peripheral and brain $\mathrm{AT}_{1}$ receptors could be of therapeutic relevance in the control of the stress reaction (Armando et al, 2001).

In addition to the hypothalamus, brain $\mathrm{AT}_{1}$ receptors are expressed in many other areas including the cortex, indicating the possibility of a role of Ang II in behavior (Tsutsumi and Saavedra, 1991a; Lenkei et al, 1998). Overexpression of $\mathrm{AT}_{1}$ receptors in mice lacking $\mathrm{AT}_{2}$ receptors (Armando et al, 2002) associates with anxietylike behavior (Okuyama et al, 1999). Of particular interest was the finding that peripheral administration of the $\mathrm{AT}_{1}$ receptor antagonist losartan reduces anxiety in rodents (Barnes et al, 1990). These findings suggest that $\mathrm{AT}_{1}$ receptor stimulation enhances anxiety and that these receptors regulate not only the autonomic and hormonal but also the behavioral response to stress.

We asked the question whether $\mathrm{AT}_{1}$ receptor antagonists could modulate the response of cortical and subcortical structures to stress. We focused on systems that play recognized roles in stress and anxiety, the cortical, amygdaloid, and septal CRF receptors, cortical benzodiazepine binding sites (part of the inhibitory $\mathrm{GABA}_{\mathrm{A}}$ complex) (Nutt and Malizia, 2001; Zavala, 1997; Biggio et al, 1990), and tyrosine hydroxylase (TH) in the locus coeruleus, the site of origin of noradrenergic neurons innervating the cortex (Koob, 1999; Dunn and Berridge, 1990; Whitnall, 1993). We tested the effects of long-term pretreatment with an $\mathrm{AT}_{1}$ antagonist on cortical and subcortical CRF and cortical benzodiazepine receptor binding and TH mRNA in the locus coeruleus in animals subjected to isolation stress, and studied the effect of a similar treatment on the behavior of the animals in the elevated plus-maze, a conflict test reflecting anxiety (Lister, 1987).

\section{MATERIALS AND METHODS}

\section{Animals and Preparation of Tissues}

Wistar Hannover male rats (8 weeks old) were purchased from Taconic Farms, Germantown, NY, kept at $22^{\circ} \mathrm{C}$ under a 12:12-h dark-light cycle with lights on at 0700 hours and were given free access to normal rat diet and tap water. The NIMH Animal Care and Use Committee approved all procedures. All efforts were made to minimize the number of animals used and their suffering (NIH Guide for the Care and Use of Laboratory Animals, NIH Publication No. 80-23, revised 1996).

We used different groups of six rats each to determine (a) Ang II receptor type binding and $\mathrm{TH}$ mRNA, (b) CRF receptor and benzodiazepine binding, and (c) behavior in the elevated plus-maze.

\section{Experiment 1. Determination of Ang II Receptor Binding and TH mRNA}

Rats were anesthetized with pentobarbital $(30 \mathrm{mg} / \mathrm{kg})$, and Alzet osmotic minipumps (Alza Scientific Products, Palo Alto, CA) were implanted subcutaneously. Groups of animals received minipumps containing vehicle or candesartan (ASTRA, Mölndal, Sweden) dissolved in $1 \mathrm{~mol} / \mathrm{l}$ sodium carbonate and further diluted in isotonic saline, at a final $\mathrm{pH}$ of $7.5-8.0$, to be delivered at a rate of $0.5 \mathrm{mg} / \mathrm{kg} / \mathrm{day}$. The dose of $0.5 \mathrm{mg} / \mathrm{kg} /$ day was selected because it produced a very significant decrease in binding to brain $\mathrm{AT}_{1}$ receptors (Nishimura et al, 2000) and was effective in blocking the sympathoadrenal and hormonal response to isolation stress (Armando et al, 2001). After minipump implantation, the rats were kept in their cages in groups of 3-4 for 13 days.

For the isolation experiments, at the end of day 13 of treatment, animals treated with candesartan or vehicle were individually housed in standard, 50 square inch plastic metabolic cages (Nalgene, Rochester, NY) that were located in the same animal room. Control animals (referred as grouped rats) treated with candesartan $0.5 \mathrm{mg} / \mathrm{kg} /$ day or vehicle remained grouped 3-4 animals per cage and undisturbed in the same animal room as the isolated rats. Regular rat food and water were provided ad libitum throughout the experiment. At the end of the experiment, on day 14, all animals were killed by decapitation and the brains were removed, frozen in isopentane at $-30^{\circ} \mathrm{C}$ on dry ice, and stored at $-80^{\circ} \mathrm{C}$ until used. These animals were used to determine Ang II receptor binding and TH mRNA as described below.

\section{Experiment 2. Autoradiographic Determination of CRF Receptor and Benzodiazepine Binding}

Additional groups of 8-week-old Wistar Hannover rats were housed, treated as above with vehicle or candesartan for 13 days, submitted to isolation stress, killed at the end of day 14 , and the brains were removed and processed as described above. These animals were used to determine CRF and benzodiazepine receptor binding as described below.

\section{Experiment 3. Study on the Elevated Plus-Maze}

Additional groups of 8-week-old Wistar Hannover rats were housed in groups of three to four rats and treated as above 
with vehicle or candesartan for 13 days. On day 14, between 0900 and 1100, the animals were tested in the elevated plusmaze as described below.

\section{Ang II Receptor Binding}

We cut $16-\mu$ m-thick brain coronal sections in a cryostat at $-20^{\circ} \mathrm{C}$, thaw-mounted the sections on poly-1-lysine-coated slides (Labscientific Inc., Livingston, NJ), dried them overnight in a desiccator at $4^{\circ} \mathrm{C}$, and stored them at $-80^{\circ} \mathrm{C}$ until used. Sections were labeled in vitro with $0.5 \mathrm{nM}$ of $\left[{ }^{125} \mathrm{I}\right]$ Sarcosine ${ }^{1}$-Ang II $\left(\left[{ }^{125} \mathrm{I}\right] \mathrm{Sar}^{1}\right.$-Ang II, Peninsula Laboratories, Belmont, CA; iodinated by the Peptide Radioiodination Service Center, School of Pharmacy, University of Mississippi, to a specific activity of $2176 \mathrm{Ci} /$ $\mathrm{mmol}$ ). Sections were preincubated for $15 \mathrm{~min}$ at $22^{\circ} \mathrm{C}$ in

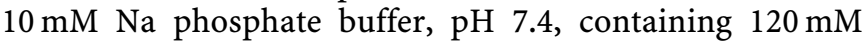
$\mathrm{NaCl}, 5 \mathrm{mM} \mathrm{Na}{ }_{2} \mathrm{EDTA}, 0.005 \%$ bacitracin (Sigma Chemical, St Louis, MO), and $0.2 \%$ bovine serum albumin proteinase free (Sigma Chemical), followed by incubation for $120 \mathrm{~min}$ in fresh buffer containing $0.5 \mathrm{nM}$ of $\left[{ }^{125} \mathrm{I}\right] \mathrm{Sar}^{1}$-Ang II. We determined total binding by incubating the sections as described above (Tsutsumi and Saavedra, 1991a). Nonspecific binding was determined in consecutive sections incubated as above in the presence of $1 \mu \mathrm{M}$ unlabeled Ang II (Peninsula), and was the binding remaining in the presence of excess unlabeled agonist. Specific binding to all Ang II receptors was the difference between total binding and nonspecific binding, which is the binding displaced by excess labeled agonist. To determine selective binding to the Ang II receptor types ( $\mathrm{AT}_{1}$ and $\mathrm{AT}_{2}$ receptors), we incubated consecutive sections with $0.5 \mathrm{nM}$ of ${ }^{125} \mathrm{I}^{12} \mathrm{Sar}^{1}$ Ang II in the presence of concentrations of the selective $\mathrm{AT}_{1}$ receptor antagonist losartan $(10 \mu \mathrm{M}$; DuPont-Merck, Wilmington, DE, USA) or the selective $\mathrm{AT}_{2}$ receptor antagonist PD 123319 ( $1 \mu \mathrm{M}$; Sigma), selected to give maximum specific displacement. The number of $\mathrm{AT}_{1}$ and $\mathrm{AT}_{2}$ receptors was the binding displaced by the $\mathrm{AT}_{1}$ or $\mathrm{AT}_{2}$ receptor antagonists, respectively (Tsutsumi and Saavedra, 1991a).

After incubation, slides were rinsed four consecutive times, for $1 \mathrm{~min}$ each, in fresh ice-cold $50 \mathrm{mM}$ Tris(hydroxymethyl)aminomethane. $\mathrm{HCl}$ buffer, $\mathrm{pH}$ 7.6, followed by a dip in ice-cold distilled water, and the sections were dried under air (Tsutsumi and Saavedra, 1991a). Sections were exposed to Kodak Biomax MR film (Eastman Kodak Company, Rochester, NY) together with ${ }^{14} \mathrm{C}$-labeled microscales (American Radiolabeled Chemicals, St Louis, MO). Films were developed in ice-cold GBX developer (Eastman Kodak) for $4 \mathrm{~min}$, fixed in Kodak GBX fixer for $4 \mathrm{~min}$ at $22^{\circ} \mathrm{C}$, and rinsed in water for $15 \mathrm{~min}$. Optical densities of autoradiograms generated by incubation with the ${ }^{125}$ I-labeled ligands were normalized after comparison with ${ }^{14}$ C-labeled standards as described (Miller and Zahniser, 1987), by computerized densitometry using the Image 1.6 Program (National Institute of Mental Health, Bethesda, MD). The films were exposed for different times, depending on the amount of binding present, to obtain film images within the linear portion of the standard curve and transformed to corresponding values of $\mathrm{fmol} / \mathrm{mg}$ protein (Nazarali et al, 1989; Miller and Zahniser, 1987). Because we used single ligand concentrations below saturation, there is no information as to whether the changes described represent alterations in receptor number or receptor affinity. Each animal was quantified independently. Brain regions were identified according to Paxinos and Watson (1986) by staining of consecutive sections with toluidine blue.

\section{In Situ Hybridization of TH mRNA}

For in situ hybridization experiments, $16-\mu \mathrm{m}$-thick brain sections consecutive to those used for receptor binding were collected as mentioned above and stored at $-80^{\circ} \mathrm{C}$ until assayed. We synthesized one antisense oligonucleotide of 48-mer for the rat TH cDNA sequence (Lofstrand Labs Limited, MD), localized in nt 1562-1609 (Grima et al, 1985), and labeled the oligonucleotide with terminal deoxynucleotidyl transferase (Amersham) to a specific activity of 3$4 \times 10^{8} \mathrm{dpm} / \mu \mathrm{g}$. Each reaction was performed with $70 \mathrm{pmol}$ of oligonucleotides in the presence of $70 \mu \mathrm{Ci}$ of $\left[\alpha-{ }^{35} \mathrm{~S}\right] \mathrm{ATP}$ (Amersham). The labeled oligonucleotides were separated from unincorporated nucleotides using MicroSpin G-25 columns (Amersham). In situ hybridization of rat brain sections and posthybridization washings were performed as described (Wisden and Morris, 1994) in consecutive brain sections, one incubated with labeled antisense oligonucleotide and another with labeled oligonucleotide in the presence of excess unlabeled probe (157 pmol/ml). After exposure to BioMax MR films (Kodak), the films were developed and quantified by comparison with ${ }^{14} \mathrm{C}$-labeled standards (American Radiolabeled Chemicals).

\section{Autoradiography of CRF Receptors}

We cut $16-\mu \mathrm{m}$-thick brain coronal sections in a cryostat at $-20^{\circ} \mathrm{C}$, thaw-mounted the sections on poly-1-lysine-coated slides (Labscientific Inc., Livingston, NJ), dried them overnight in a desiccator at $4^{\circ} \mathrm{C}$, and stored them at $-80^{\circ} \mathrm{C}$ until used.

Consecutive brain sections were preincubated twice for

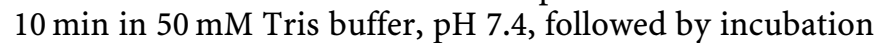
for $60 \mathrm{~min}$ at room temperature in $50 \mathrm{mM}$ Tris buffer, $\mathrm{pH}$ 7.4, containing $10 \mathrm{mM} \mathrm{MgCl}_{2}, 0.1 \%$ BSA, $0.05 \%$ bacitracin, and $0.2 \mathrm{nM}\left[{ }^{125} \mathrm{I}\right]$ sauvagine (specific activity $2200 \mathrm{Ci} / \mathrm{mmol}$; Perkin-Elmer, Boston, MA) to label both $\mathrm{CRF}_{1}$ and $\mathrm{CRF}_{2}$ receptor subtypes (Rominger et al, 1998). Consecutive sections were used to determine selective binding to $\mathrm{CRF}_{1}$ and $\mathrm{CRF}_{2}$ receptors. Binding to both $\mathrm{CRF}_{1}$ and $\mathrm{CRF}_{2}$ receptors was calculated as the binding of $\left[{ }^{125} \mathrm{I}\right]$ sauvagine displaced by $1 \mu \mathrm{M}$ human CRF (Peninsula). The binding not displaced by $1 \mu \mathrm{M}$ human $\mathrm{CRF}$ was defined as nonspecific binding. Binding to $\mathrm{CRF}_{1}$ receptors was the $\left[{ }^{125} \mathrm{I}\right]$ sauvagine binding displaced by $13 \mathrm{nM}$ of the selective $\mathrm{CRF}_{1}$ receptor antagonist antalarmin (Rominger et al, 1998; Schulz et al, 1996; Webster et al, 1996; McCarthy et al, 1999). The $\left[{ }^{125} \mathrm{I}\right]$ sauvagine binding not displaced by antalarmin but displaced in the presence of $1 \mu \mathrm{M}$ hCRF was considered as binding to $\mathrm{CRF}_{2}$ receptors. Following the incubation period, slides were washed twice, $5 \mathrm{~min}$ each, in Tris buffer $(50 \mathrm{mM})$ containing $0.01 \%$ Triton $\mathrm{X}-100$ at $4{ }^{\circ} \mathrm{C}$. Slides were washed in deionized water, dried under cold air, exposed to Kodak Biomax MR film (Eastman Kodak Company, Rochester, $\mathrm{NY}$ ) together with ${ }^{14} \mathrm{C}$-labeled standards, and developed and 
quantified as described above. Cortical areas (cingulate, frontal, and parietal), the lateral septal nucleus, and the amygdaloid complex were defined according to Paxinos and Watson (1986).

\section{Autoradiography of Benzodiazepine Binding Sites}

Brain sections (16- $\mu \mathrm{m}$-thick) were incubated for $90 \mathrm{~min}$ at $4{ }^{\circ} \mathrm{C}$ in assay buffer $(50 \mathrm{mM}$ Tris-citrate $\mathrm{pH} 7.1$ containing $150 \mathrm{mM} \mathrm{NaCl}$ ) and $1 \mathrm{nM}$ of the nonselective benzodiazepine agonist $\left[{ }^{3} \mathrm{H}\right]$ flunitrazepam $(71.0 \mathrm{Ci} / \mathrm{mmol}$; Perkin Elmer, Boston, MA). The binding of $\left[{ }^{3} \mathrm{H}\right]$ flunitrazepam displaced in the presence of $1 \mu \mathrm{M}$ clonazepam in consecutive sections was considered as binding to central benzodiazepine receptors (BZ1 and BZ2) (Negro et al, 1995; FernándezLópez et al, 1997). After incubation, sections were washed five times for $5 \mathrm{~min}$ in incubation buffer at $4{ }^{\circ} \mathrm{C}$ and dipped once in ice-cold distilled water. Slides were dried and exposed to Kodak Biomax MR film for 1 week together with ${ }^{3} \mathrm{H}$-labeled standards. Films were developed as above, and images quantified as described above with comparison to ${ }^{3} \mathrm{H}$-labeled standards (Orchinik et al, 2001). Cortical areas were defined as above (Paxinos and Watson, 1986).

\section{Elevated Plus-Maze}

The plus-maze apparatus was made of stainless steel and consisted of four arms elevated $50 \mathrm{~cm}$ above the ground, with each arm $\left(50 \mathrm{~cm}\right.$ long and $10 \mathrm{~cm}$ wide) positioned $90^{\circ}$ relative to the adjacent. The arms extended from a central platform with two closed arms (walls $40 \mathrm{~cm}$ high) and two open arms (Columbus Instruments, Columbus, $\mathrm{OH}$ ). Testing was conducted in a quiet room. To facilitate adaptation, the animals were placed in the behavioral room $1 \mathrm{~h}$ before testing.

Rats were placed in the center of the plus-maze facing an open arm (Rodgers and Johnson, 1998), and we recorded the percent of time spent in the open arms and the number of entries in the open and closed arms. Arm entry was defined as placing all four paws on it, and the duration of the test was $5 \mathrm{~min}$ for each animal (Montgomery, 1955).

\section{Statistics}

Data are means $\pm S E M$, for groups of six animals measured individually. Two-way ANOVA followed by the NewmanKeuls test was used to assess the significance of differences in receptor binding, TH mRNA, and CRF content among groups. Unpaired Student's $t$-test was used to assess the significance of differences in the behavior display in the plus-maze. $p<0.05$ was considered as statistically significant.

\section{RESULTS}

Effect of Isolation and $\mathrm{AT}_{1}$ Antagonism on Expression of Ang II Receptors and TH mRNA in the Brain

In grouped animals, subcutaneous administration of the $\mathrm{AT}_{1}$ antagonist for 14 days substantially decreased the binding to $\mathrm{AT}_{1}$ receptors in all areas studied. The binding to $\mathrm{AT}_{2}$ receptors was not affected by the treatment (Table 1). The significant reduction in binding to $\mathrm{AT}_{1}$ receptors
Table I Quantification of Ang II Receptor Types (AT, and AT 2 ) in Brain Areas by Autoradiography

\begin{tabular}{|c|c|c|c|c|}
\hline & \multicolumn{2}{|c|}{$\begin{array}{c}\text { Vehicle } \\
\text { (fmol/mg protein) }\end{array}$} & \multicolumn{2}{|c|}{$\begin{array}{c}A T_{1} \text { antagonist } \\
\text { (fmol/mg protein) }\end{array}$} \\
\hline & Grouped & Isolation & Grouped & Isolation \\
\hline \multicolumn{5}{|l|}{$A T$, receptors } \\
\hline \multicolumn{5}{|l|}{ Forebrain } \\
\hline Subfornical organ & $49 \pm 9$ & $94 \pm 16^{* * *}$ & $14 \pm 2 *$ & $18 \pm 7 *$ \\
\hline PVN & $30 \pm 4$ & $60 \pm 7^{* * *}$ & $10 \pm 1 *$ & $12 \pm 2 *$ \\
\hline \multicolumn{5}{|l|}{ Brainstem } \\
\hline $\begin{array}{l}\text { Nucleus of the solitary } \\
\text { tract }\end{array}$ & $56 \pm 6$ & $82 \pm 3 * *$ & $23 \pm 2 *$ & $16 \pm 5^{*}$ \\
\hline Area postrema & $29 \pm 5$ & $4 I \pm 7^{* * *}$ & $14 \pm 2 *$ & $10 \pm 3 *$ \\
\hline \multicolumn{5}{|l|}{$A T_{2}$ receptors } \\
\hline \multicolumn{5}{|l|}{ Brainstem } \\
\hline Locus coeruleus & $12 \pm 1$ & $5 \pm 1 * * *$ & $10 \pm 1$ & $10 \pm 1$ \\
\hline $\begin{array}{l}\text { Inferior olive medial } \\
\text { nucleus }\end{array}$ & $16 \pm 1$ & $13 \pm 1^{\#}$ & $15 \pm 1$ & $15 \pm 1$ \\
\hline $\begin{array}{l}\text { Inferior olive medial } \\
\text { subnucleus } A \text { and } B\end{array}$ & $17 \pm 1$ & ||$\pm\left.\right|^{\#}$ & $14 \pm 2$ & $16 \pm 1$ \\
\hline
\end{tabular}

Values are means \pm SEM for groups of six rats, measured individually as described under Materials and methods, and are expressed as fmol/mg protein *Significantly different from grouped and isolated treated with vehicle, **Significantly different from all others, " significantly different from grouped vehicle, $p<0.05$.

in grouped, nonstressed animals very likely represents insurmountable binding of candesartan (Nishimura et al, 2000; Armando et al, 2001).

In vehicle-treated animals, isolation increased significantly $\mathrm{AT}_{1}$ binding in the PVN, subfornical organ, nucleus of the solitary tract, and area postrema (Table 1). Conversely, isolation significantly decreased the binding to $\mathrm{AT}_{2}$ receptors in the locus coeruleus and inferior olive (Table 1 and Figure 1). Pretreatment of the animals with the $\mathrm{AT}_{1}$ antagonist abolished the increase in $\mathrm{AT}_{1}$ receptors in all areas studied and reversed the decrease in $\mathrm{AT}_{2}$ binding in the locus coeruleus and the inferior olive (Table 1 and Figure 1).

Administration of the $\mathrm{AT}_{1}$ antagonist to grouped animals had no effect on the expression of TH mRNA in the locus coeruleus. Isolation significantly increased TH mRNA in vehicle-treated animals, and pretreatment with the $\mathrm{AT}_{1}$ antagonist completely prevented the isolation-induced increase in TH mRNA (Figure 1).

\section{Effect of Isolation and $\mathrm{AT}_{1}$ Receptor Antagonism on Expression of $\mathrm{CRF}_{1}$ Receptors in Brain Cortex}

Addition of unlabeled CRF completely displaced cortical binding of $\left[{ }^{125} \mathrm{I}\right]$ sauvagine (Figure 2 ). In the cortex, most of the $\left[{ }^{125} \mathrm{I}\right]$ sauvagine binding was displaced by antalarmin, indicating a predominance of $\mathrm{CRF}_{1}$ receptors (Figure 2). $\mathrm{CRF}_{1}$ binding was unevenly distributed in the parietal cortex, with layer IV, corresponding to the granular layer, 
expressing about two-fold higher binding than cortical layers I-III and V-VI (Figures 2-4).

The number of cortical $\mathrm{CRF}_{2}$ receptors (binding not displaced by antalarmin but displaced by unlabeled CRF) represented about $25-40 \%$ of the total binding to CRF
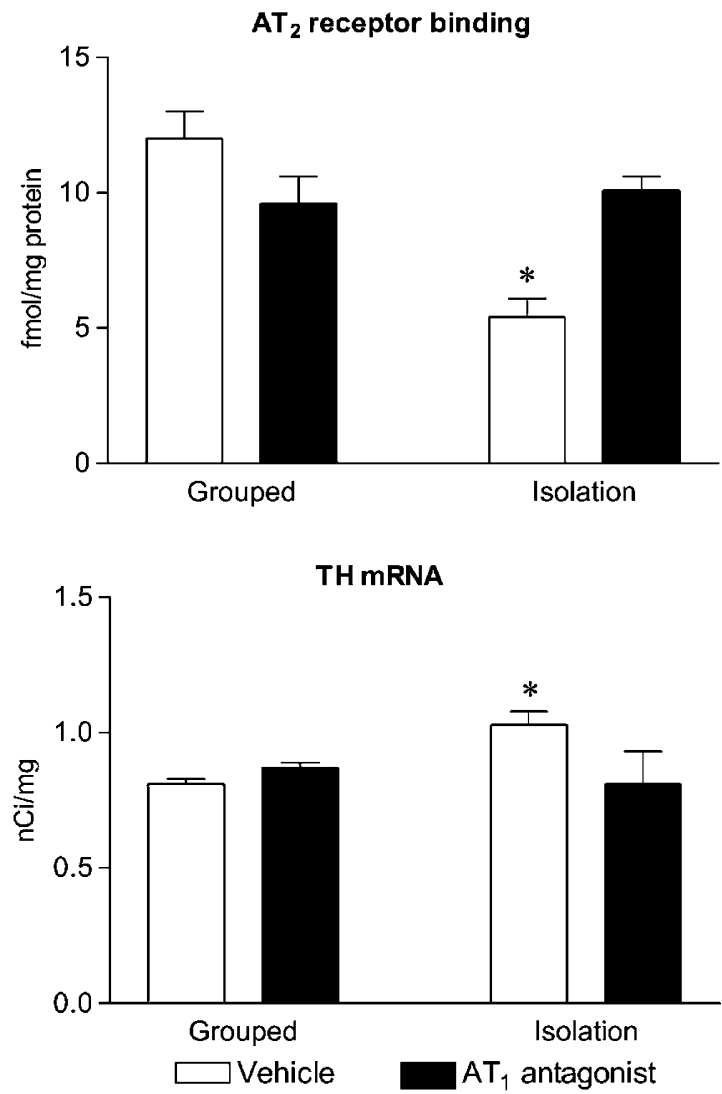

Figure I Quantification of $A T_{2}$ receptors and of in situ hybridization of TH mRNA in the locus coeruleus. Grouped or isolated rats were treated for 14 days with vehicle or the AT, receptor antagonist. Values are means \pm SEM for groups of six rats, measured individually as described under Materials and methods. ${ }^{*} p<0.05$ as compared to all others. receptors (Table 2 and Figure 2). Higher numbers of $\mathrm{CRF}_{2}$ receptors were expressed in layer IV of the parietal cortex (Table 2).

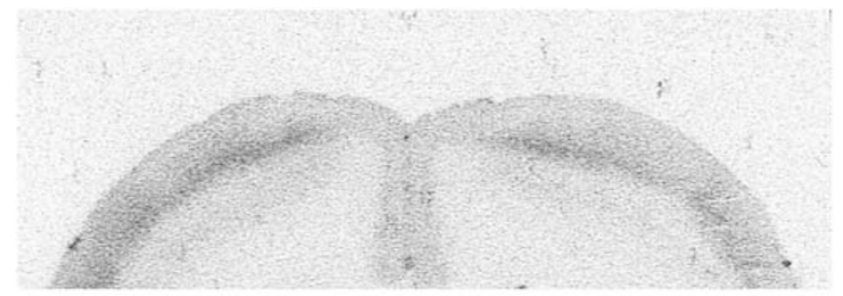

$\left[{ }^{125}\right]$-sauvagine

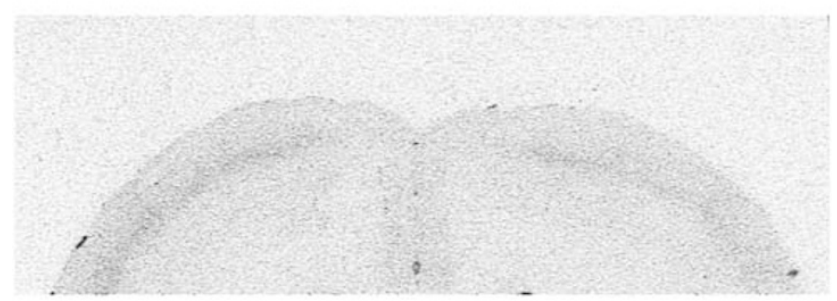

$\left[{ }^{125}\right]$-sauvagine + Antalarmin

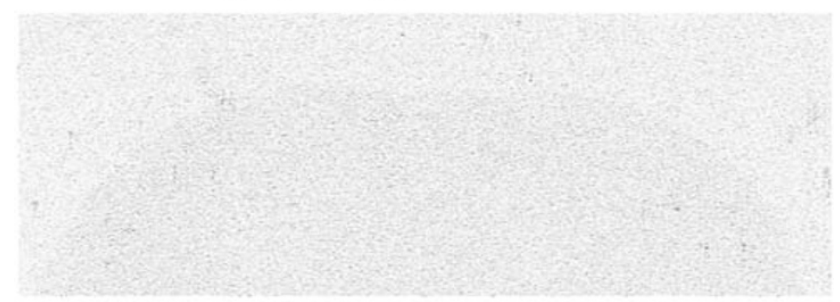

[ $\left.{ }^{125}\right]$-sauvagine + CRF

Figure 2 Autoradiography of CRF receptor types in the rat cortex. Upper figure: Autoradiographic images of cortical sections incubated in the presence of $0.2 \mathrm{nM}$ of $\left[{ }^{125} \mid\right]$ sauvagine to reveal CRF receptors. Middle figure: Consecutive section incubated as above with addition of antalarmin to displace binding to $C R F$, receptors. Lower figure: Consecutive section incubated as above with addition of unlabeled CRF to displace binding to $\mathrm{CRF}_{1}$ and $\mathrm{CRF}_{2}$ receptors (see Materials and methods).
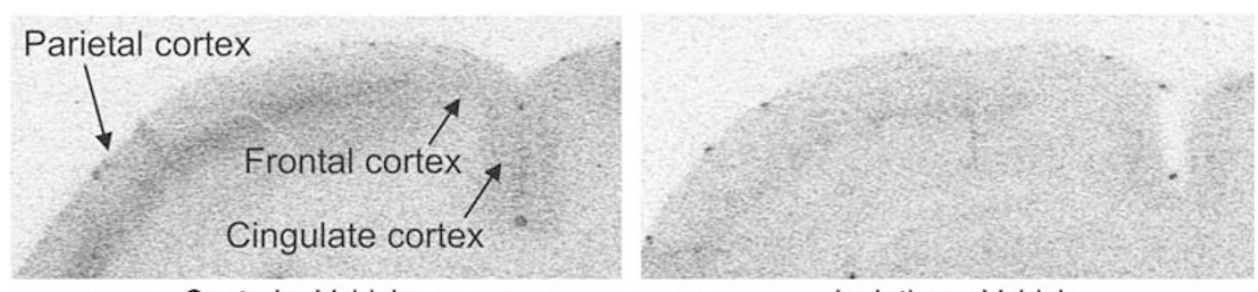

Control + Vehicle

Isolation + Vehicle

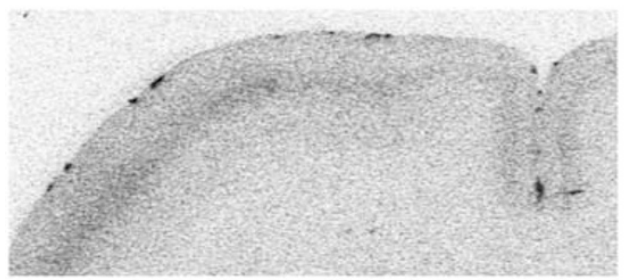

Control $+\mathrm{AT}_{1}$ antagonist

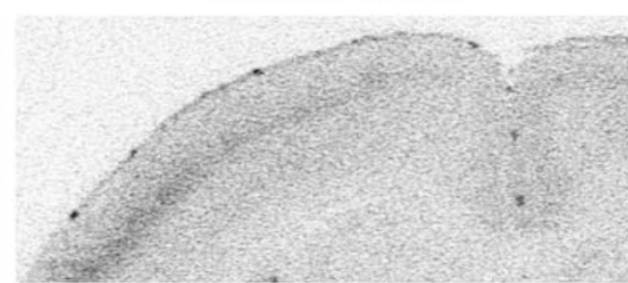

Isolation $+\mathrm{AT}_{1}$ antagonist

Figure 3 Representative autoradiography of CRF receptor binding in cortex. Grouped or isolated rats were treated for I4 days with vehicle or the AT, antagonist. Sections were incubated with [ $\left.{ }^{\mid 25} \mid\right]$ sauvagine as described in Materials and methods and represent total binding. Note that the decreased cortical binding in isolated animals treated with vehicle was prevented by pretreatment with the AT, receptor antagonist. 

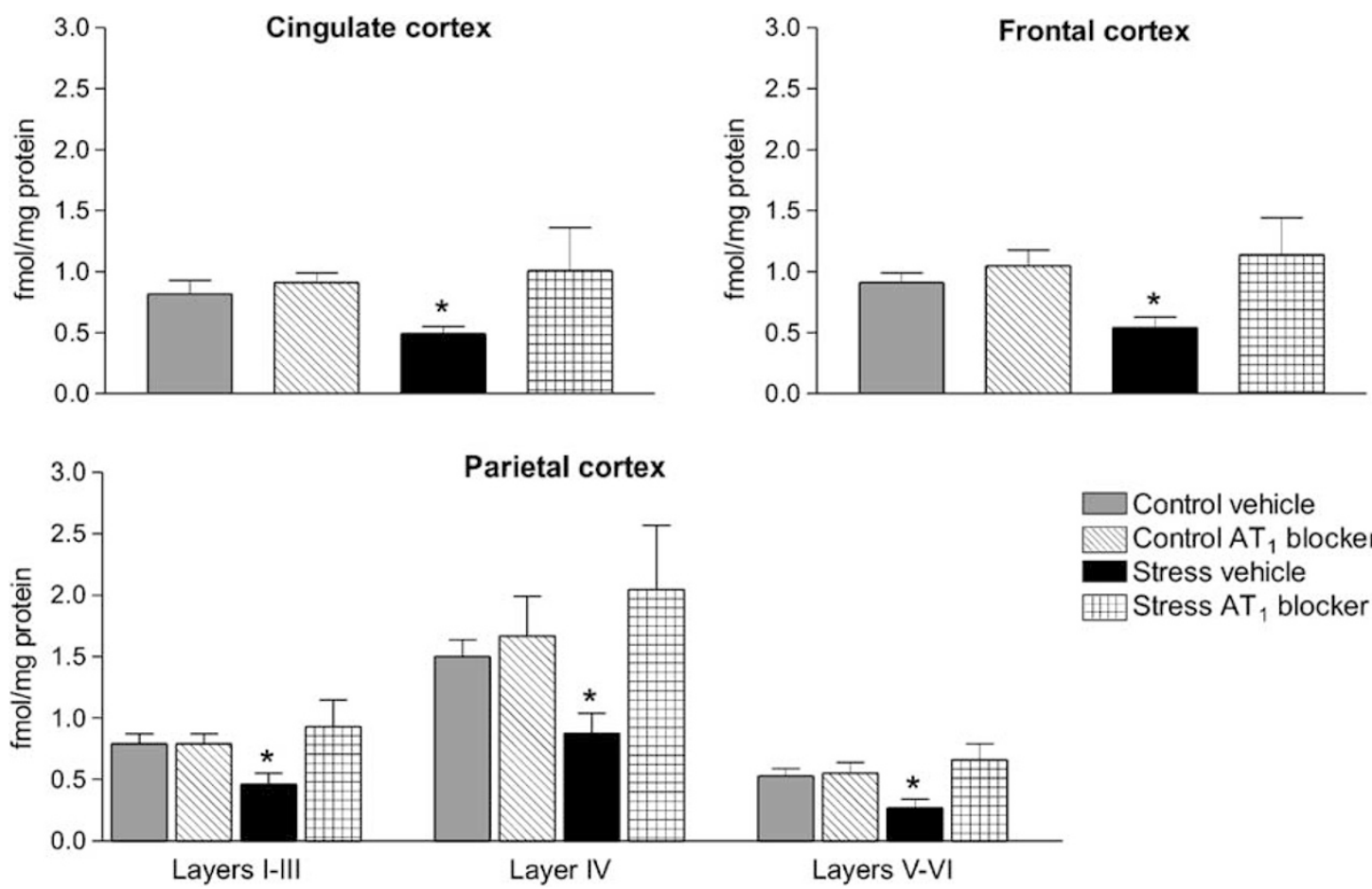

Figure 4 Quantification of CRF, receptors in the cingulate, frontal, and parietal cortex. Grouped or isolated animals were treated with vehicle or the AT, antagonist. Values are means \pm SEM for groups of six rats, measured individually as described under Materials and methods, and are expressed as fmol/mg protein. ${ }^{*} p<0.05$ as compared to all other experimental groups.

Table 2 Quantification of $\mathrm{CRF}_{2}$ Receptors in the Cingulate, Frontal, and Parietal Cortex of Grouped and Isolated Rats Treated with Vehicle or AT, Antagonist

\begin{tabular}{|c|c|c|c|c|}
\hline & \multicolumn{2}{|c|}{$\begin{array}{c}\text { Vehicle } \\
\text { (fmol/mg protein) }\end{array}$} & \multicolumn{2}{|c|}{$\begin{array}{c}\text { AT }, \text { antagonist } \\
\text { (fmol/mg protein) }\end{array}$} \\
\hline & Grouped & Isolation & Grouped & Isolation \\
\hline Cingulate cortex & $0.54 \pm 0.10$ & $0.43 \pm 0.04$ & $0.46 \pm 0.11$ & $0.50 \pm 0.05$ \\
\hline Frontal cortex & $0.44 \pm 0.09$ & $0.32 \pm 0.02$ & $0.35 \pm 0.08$ & $0.38 \pm 0.05$ \\
\hline \multicolumn{5}{|l|}{ Parietal cortex } \\
\hline Layers I-III & $0.53 \pm 0.08$ & $0.40 \pm 0.06$ & $0.56 \pm 0.20$ & $0.47 \pm 0.09$ \\
\hline Layer IV & $0.86 \pm 0.16$ & $0.54 \pm 0.07$ & $0.73 \pm 0.20$ & $0.59 \pm 0.08$ \\
\hline Layers V-VI & $0.53 \pm 0.11$ & $0.42 \pm 0.05$ & $0.49 \pm 0.16$ & $0.47 \pm 0.02$ \\
\hline
\end{tabular}

Values are means \pm SEM for groups of four to six rats, measured individually as described under Materials and methods, and are expressed as fmol/mg protein.

Pretreatment of grouped animals with the $\mathrm{AT}_{1}$ antagonist had no effect on the binding of $\left[{ }^{125} \mathrm{I}\right]$ sauvagine to $\mathrm{CRF}_{1}$ receptors in any of the brain cortical areas examined (Figure 4). Isolation significantly decreased $\mathrm{CRF}_{1}$ receptor binding, about $35-40 \%$, in all cortical layers examined (Figures 3 and 4). In all cortical layers, pretreatment with the $\mathrm{AT}_{1}$ antagonist completely prevented the decrease in $\mathrm{CRF}_{1}$ binding, which occurred in animals subjected to isolation stress (Figures 3 and 4).

Conversely, the expression of $\mathrm{CRF}_{2}$ receptors was not significantly altered by isolation or pretreatment with the
$\mathrm{AT}_{1}$ receptor antagonist, in any of the cortical areas studied (Table 2).

\section{Effect of Isolation and $\mathrm{AT}_{1}$ Receptor Antagonism on Expression of CRF Receptors in Septum and Amygdala}

In the lateral septum, only $\mathrm{CRF}_{2}$, but not $\mathrm{CRF}_{1}$, receptors were expressed. There was no significant change in $\mathrm{CRF}_{2}$ receptors when grouped animals were treated with candesartan, and no significant changes in $\mathrm{CRF}_{2}$ receptor expression were detected after isolation. Pretreatment of isolated animals with candesartan produced a small (15\%) but statistically significant increase in $\mathrm{CRF}_{2}$ receptor expression. Values were $2.38 \pm 0.20$, $2.08 \pm 0.25,2.19 \pm 0.15$, and $2.53 \pm 0.12 \mathrm{fmol} / \mathrm{mg}$ protein for grouped, grouped treated with candesartan, isolated, and isolated treated with candesartan, respectively $(p<0.05$, isolated treated with candesartan $v s$ all other groups).

In the amygdala complex, we detected both $\mathrm{CRF}_{1}$ and $\mathrm{CRF}_{2}$ receptors. There were no significant changes in expression of either receptor type after treatment of grouped animals with candesartan, after isolation, or after pretreating isolated animals with candesartan. Values for $\mathrm{CRF}_{1}$ receptors were $1.43 \pm 0.20,0.90 \pm 0.38$, $1.47 \pm 0.23$, and $0.99 \pm 0.21 \mathrm{fmol} / \mathrm{mg}$ protein, respectively, for grouped, grouped treated with candesartan, isolated, and isolated pretreated with candesartan $(p>0.05)$. Values for $\mathrm{CRF}_{2}$ receptors were $1.86 \pm 0.17$, $1.97 \pm 0.18, \quad 1.41 \pm 0.20$, and $1.77 \pm 0.20 \mathrm{fmol} / \mathrm{mg}$ protein, respectively, for grouped, grouped treated with candesartan, isolated, and isolated pretreated with candesar$\tan (p>0.05)$. 
Effect of Isolation and $\mathrm{AT}_{1}$ Receptor Antagonism on Expression of Central Benzodiazepine Binding Sites in Brain Cortex

The binding of $\left[{ }^{3} \mathrm{H}\right]$ flunitrazepam to cortical areas was completely displaced by $1 \mu \mathrm{M}$ clonazepam, indicating

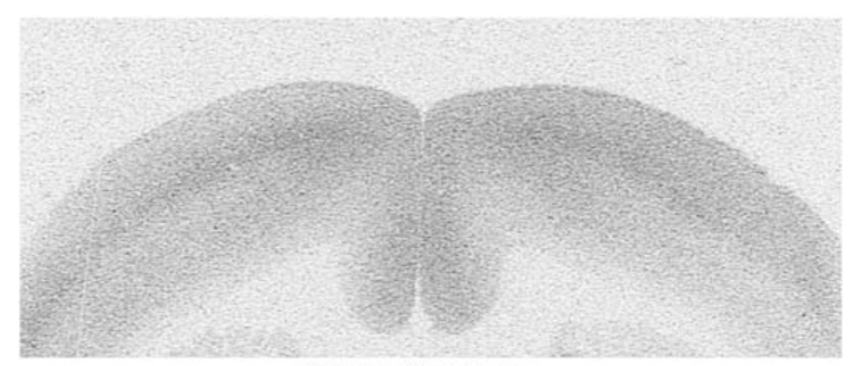

$\left[{ }^{3} \mathrm{H}\right]$-flunitrazepam

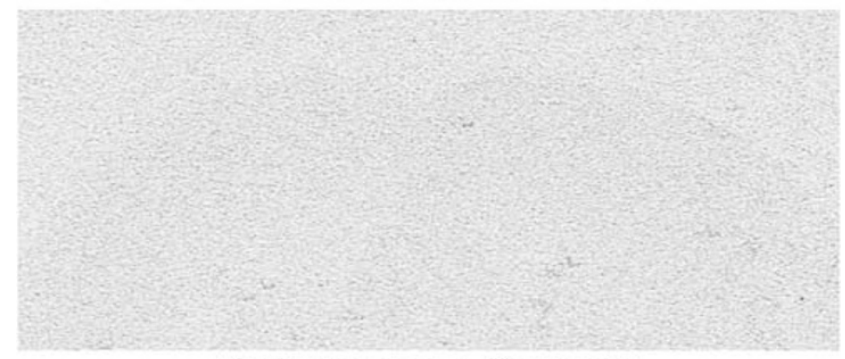

$\left[{ }^{3} \mathrm{H}\right]$-flunitrazepam + Clonazepam

Figure 5 Autoradiography of benzodiazepine binding in cortex. Upper figure: Autoradiographic images of cortical sections incubated in the presence of I nM of $\left[^{3} \mathrm{H}\right]$ flunitrazepam. Lower figure: Consecutive section incubated as above with addition of clonazepam to displace binding to benzodiazepine sites (see Materials and methods). binding to the central type benzodiazepine BZ1 and BZ2 receptors (Figure 5).

Benzodiazepine binding was unevenly distributed in the cortical areas studied. Highest binding was present in the cingulate cortex and in layer IV, corresponding to the granular layer, of the parietal cortex (Figures 5-7).

Pretreatment of the animals with the $\mathrm{AT}_{1}$ receptor antagonist did not modify the binding to central benzodiazepine receptors in grouped animals (Figures 6 and 7). In animals subjected to isolation stress, benzodiazepine binding was significantly decreased in all cortical areas studied (Figures 6 and 7), and this decrease was completely prevented by pretreatment of the animals with the $\mathrm{AT}_{1}$ receptor antagonist (Figures 6 and 7).

\section{Effect of Pretreatment with an $\mathrm{AT}_{1}$ Receptor Antagonist on the Behavior in the Elevated Plus-Maze}

Administration of the $\mathrm{AT}_{1}$ antagonist to grouped animals for 13 days before the testing increased the number of entries into open arms and increased the percent of the time spent in the open arms. Entries into closed arms were not affected by the treatment (Figure 8 ).

\section{DISCUSSION}

The main finding of this study is that pretreatment with a centrally acting Ang II $\mathrm{AT}_{1}$ receptor antagonist prevents the isolation stress-induced alterations in cortical $\mathrm{CRF}_{1}$ and benzodiazepine binding and locus coeruleus TH mRNA, and reduces anxiety in the elevated plus-maze. This indicates that $\mathrm{AT}_{1}$ receptor antagonists exert anti-stress

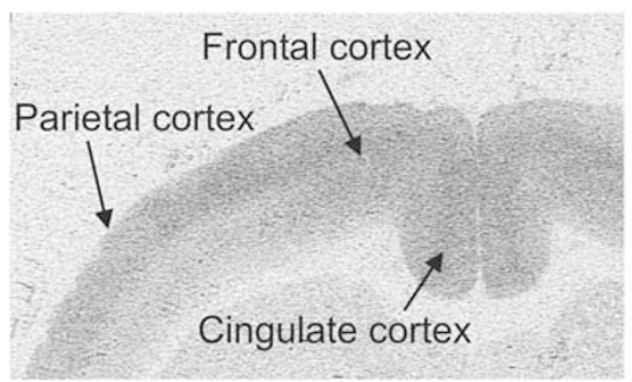

Control + Vehicle

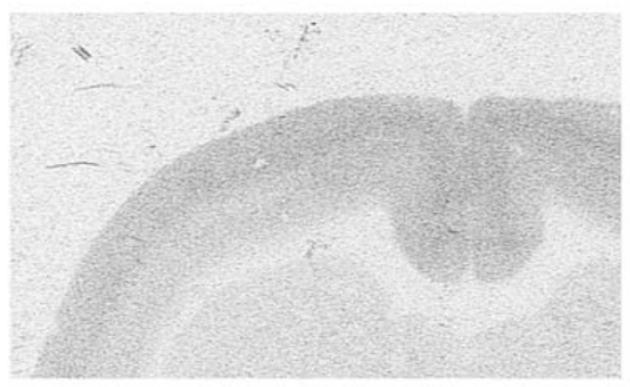

Control $+\mathrm{AT}_{1}$ antagonist

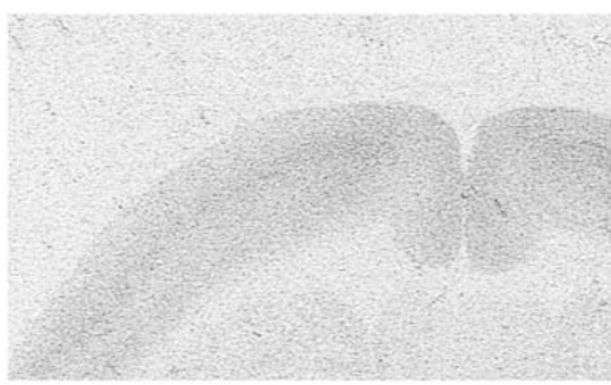

Isolation + Vehicle

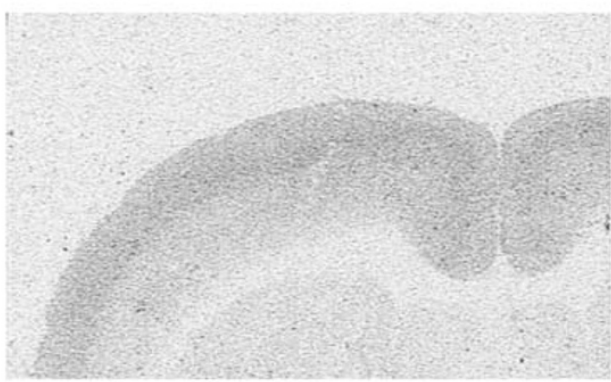

Isolation $+\mathrm{AT}_{1}$ antagonist

Figure 6 Representative autoradiography of benzodiazepine binding in cortex. Grouped or isolated rats were treated for 14 days with vehicle or the AT, antagonist. Sections were incubated with $\left.{ }^{3} \mathrm{H}\right]$ flunitrazepam as described in Materials and methods. Note that the decreased cortical binding in isolated animals treated with vehicle was prevented by pretreatment with the AT, receptor antagonist. 

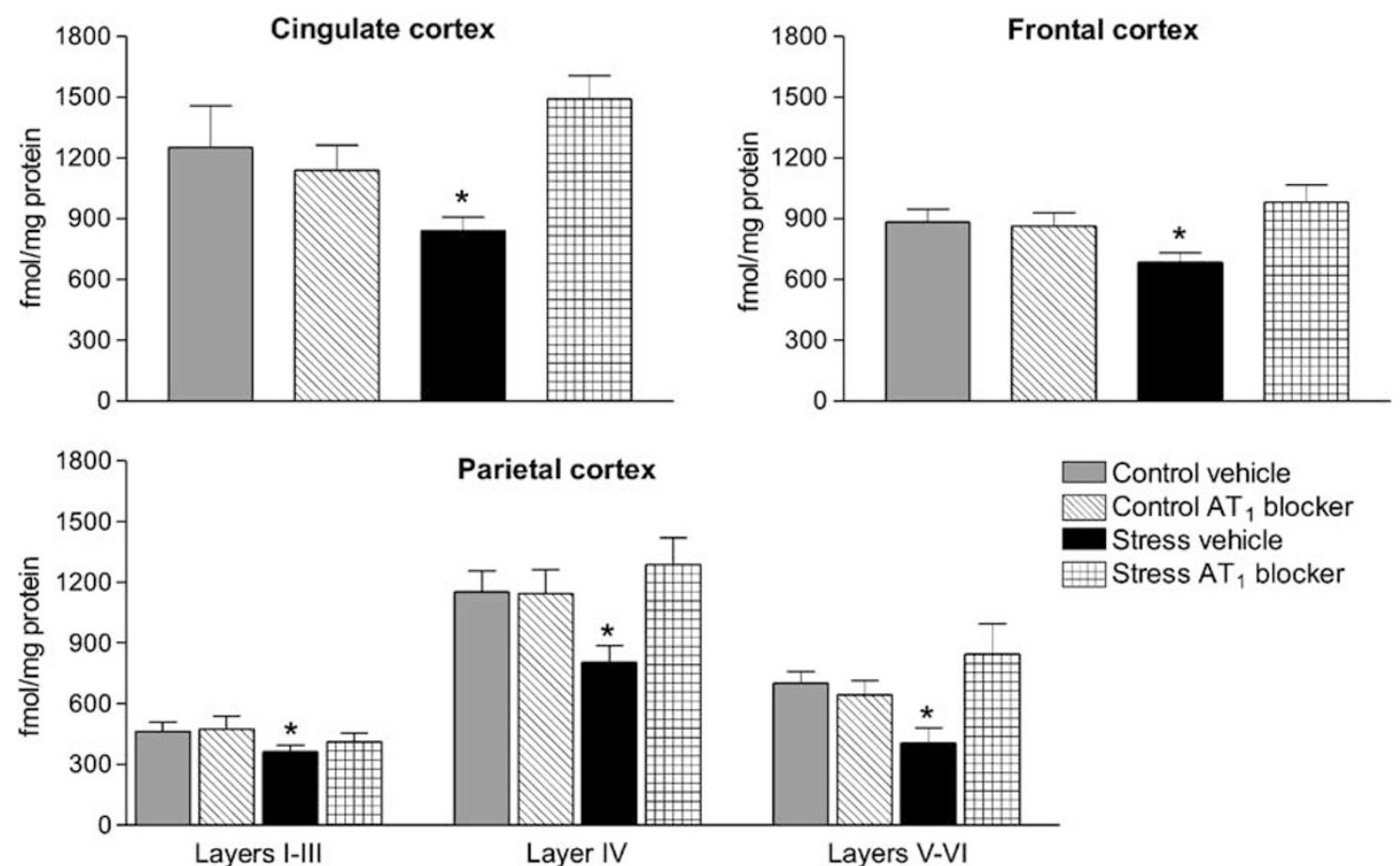

$\square$ Control vehicle

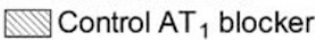

Stress vehicle - 1 Stress AT, blocker

Layers V-VI

Figure 7 Quantification of benzodiazepine receptors in the cingulate, frontal, and parietal cortex. Grouped or isolated animals were treated with vehicle or the AT, antagonist. Values are means \pm SEM for groups of six rats, measured individually as described under Materials and methods, and are expressed as $\mathrm{fmol} / \mathrm{mg}$ protein. $* 0.05$ as compared to all other experimental groups.
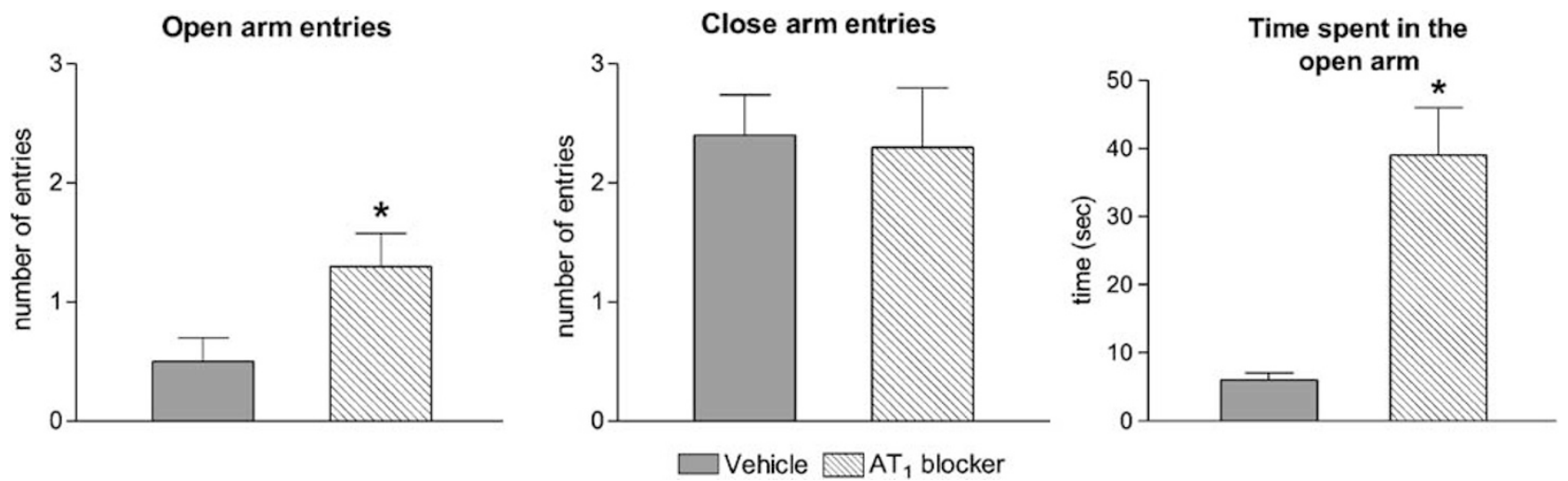

Figure 8 Behavior in the elevated plus-maze. Grouped undisturbed rats pretreated for 14 days with vehicle or the AT, antagonist were tested in the elevated plus-maze and measured individually as described under Materials and methods. Values are means \pm SEM for groups of 10 rats. * $p<0.05$ as compared to the vehicle-treated group.

and anti-anxiety properties by modulating three interacting cortical systems, CRF, $\mathrm{GABA}_{\mathrm{A}}$, and norepinephrine.

We confirmed that subcutaneous administration of the insurmountable and selective $\mathrm{AT}_{1}$ receptor antagonist candesartan blocked brain $\mathrm{AT}_{1}$ receptors, demonstrating that the compound crossed the blood-brain barrier and is an effective agent to antagonize the effects of brain Ang II (Nishimura et al, 2000; Seltzer et al, 2004). Pretreatment with the $\mathrm{AT}_{1}$ antagonist, by preventing the hormonal response to isolation, prevented the glucocorticoid-induced increase in receptor transcription (Armando et al, 2001; Leong et al, 2002; present results) and the corresponding increase in expression of $\mathrm{AT}_{1}$ receptors in the PVN (Armando et al, 2001).
The locus coeruleus, the site of origin of the sympathetic innervation to the cortex, participates in the well-characterized stress-induced central sympathetic stimulation (Carrasco and Van de Kar, 2003; Berridge and Waterhouse, 2003). $\mathrm{AT}_{1}$ stimulation enhances central norepinephrine formation and release (Saavedra, 1992). Pretreatment with $\mathrm{AT}_{1}$ antagonists prevented the sympathoadrenal response to isolation (Armando et al, 2001) and the increase in TH mRNA in the locus coeruleus after central administration of Ang II (Seltzer et al, 2004). For these reasons, it was not surprising to find that pretreatment with candesartan prevented the stress-induced increase in TH mRNA in the locus coeruleus (present results).

However, in the rat, the locus coeruleus does not express $\mathrm{AT}_{1}$ receptors, but large numbers of Ang II $\mathrm{AT}_{2}$ receptors 
(Tsutsumi and Saavedra, 1991a; present results). Isolation (present results) or cold stress (Peng and Phillips, 2001) decrease $\mathrm{AT}_{2}$ binding in the locus coeruleus, a change in opposite direction to that of forebrain and brainstem $\mathrm{AT}_{1}$ receptors during stress. We found that, in parallel with a reversal of the isolation-induced increase in TH mRNA, candesartan prevented the isolation-induced decrease in $\mathrm{AT}_{2}$ binding in the locus coeruleus. These findings suggest that, whereas brain $\mathrm{AT}_{1}$ receptors are clearly involved in the control of the central sympathetic drive through regulation of $\mathrm{TH}$ transcription, $\mathrm{AT}_{1}$ receptor antagonists prevent the stressinduced increase in central sympathetic drive by indirect effects requiring $\mathrm{AT}_{2}$ receptor participation. In support of this hypothesis, we reported a dual role for $\mathrm{AT}_{1}$ and $\mathrm{AT}_{2}$ receptors in the control of basal $\mathrm{TH}$ transcription and catecholamine formation in the adrenal medulla (Jezova et al, 2003).

The coordination of behavioral and autonomic responses to stress, including fear and anxiety (Dunn and Berridge, 1990; Whitnall, 1993; Carrasco and Van de Kar, 2003), is partially under the control of extrahypothalamic, including cortical, CRF neurons predominantly expressing $\mathrm{CRF}_{1}$ receptors (Bittencourt and Sawchenko, 2000; Chalmers

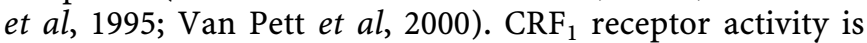
important for the induction of anxiety, and $\mathrm{CRF}_{1}$ (corticotropin-releasing hormone) receptor antagonists decrease stress-induced anxiety (Menzaghi et al, 1994; Rodriguez de Fonseca et al, 1996; Millan et al, 2001; Smith et al, 1998).

Cortical $\mathrm{CRF}_{1}$ receptor binding decreases after isolation (present results), foot shock (Anderson et al, 1993), and chronic unpredictable stress (Iredale et al, 1996). Central administration of CRF downregulated $\mathrm{CRF}_{1}$ binding in the frontal cortex (Brunson et al, 2002) and incubation of a neuron-derived cell line with CRF decreased the levels of $\mathrm{CRF}_{1}$ mRNA (Iredale et al, 1996). For these reasons, the stress-induced decrease in $\mathrm{CRF}_{1}$ receptors has been related to ligand-induced downregulation in response to increased peptide release (Carrasco and Van de Kar, 2003). In support of this hypothesis, we found a decrease in cortical CRF levels of rats submitted to cold restraint, a change prevented by pretreatment with candesartan (unpublished results).

We report that pretreatment with the $\mathrm{AT}_{1}$ antagonist candesartan prevents the isolation-induced decrease in cortical $\mathrm{CRF}_{1}$ binding. The stress-induced release of cortical CRF may be positively regulated by cortical $\mathrm{AT}_{1}$ receptor stimulation, in a manner similar to that occurring at the hypothalamic level. Autoradiographic studies revealed $\mathrm{AT}_{1}$ receptors in the entorhinal and piriform cortex, but not in the neocortex (Tsutsumi and Saavedra, 1991a), possibly because of limitations in the power of cellular resolution of the film autoradiography. However, expression on neocortical $\mathrm{AT}_{1}$ receptor mRNA was detected with in situ hybridization (Lenkei et al, 1998), indicating the existence of a cortical $\mathrm{AT}_{1}$ receptor system. Thus, blockade of cortical $\mathrm{AT}_{1}$ receptors could directly reduce CRF release and prevent $\mathrm{CRF}_{1}$ receptor downregulation. Alternatively, or in addition, $\mathrm{AT}_{1}$ receptor antagonism could prevent the stressinduced decrease on cortical $\mathrm{CRF}_{1}$ receptors by decreasing $\mathrm{TH}$ transcription in the locus coeruleus. There is a reciprocal relationship between the brain CRF and sympathetic systems, and CRH contributes to activation of the locus coeruleus during stress (Berridge and Waterhouse, 2003). Stress increases CRF concentrations in the locus coeruleus (Chappell et al, 1986), local application of CRF in the locus coeruleus induces behavioral activation (Butler et al, 1990), and i.c.v. administration of a CRF antagonist blunts the stress-induced increase in extracellular norepinephrine levels in the prefrontal cortex (Shimizu et al, 1994). This in turn could decrease CRF release from cortical neurons, as it is known that at least in the hypothalamus CRF release is under noradrenergic control (Szafarczyk et al, 1995).

In addition to $\mathrm{CRF}_{1}$ receptors, there are cortical $\mathrm{CRF}_{2}$ receptors in rats (Primus et al, 1997) and nonhuman primates (Sánchez et al, 1999). The modulatory effect of the $\mathrm{AT}_{1}$ receptor antagonist appears restricted, in cortical areas, to $\mathrm{CRF}_{1}$ receptors, as the expression of cortical $\mathrm{CRF}_{2}$ receptors is not altered by candesartan pretreatment.

The role of brain $\mathrm{AT}_{1}$ receptors may not be limited to that of regulatory functions in cortical structures, the focus of the present study, but may very well extend to subcortical limbic structures such as the amygdala, septum, and hippocampus, the site of large numbers of $\mathrm{AT}_{1}$ receptors (Tsutsumi and Saavedra, 1991a). For this reason, we examined the effects of isolation and candesartan treatment on the expression of CRF receptors in the septum and amygdaloid complex, part of a circuit that plays a major role in the regulation of the stress response (Carrasco and Van de Kar, 2003; Herman et al, 2003). In the amygdaloid complex, we found no isolation-induced alterations and no changes after candesartan treatment in $\mathrm{CRF}_{1}$ or $\mathrm{CRF}_{2}$ receptor expression, indicating that the effects of $\mathrm{AT}_{1}$ receptor blockade in $\mathrm{CRF}_{1}$ receptors may be restricted to cortical areas.

In our experiments, we did not detect significant numbers of $\mathrm{CRF}_{1}$ receptors in the lateral septum, a region with very low expression of $\mathrm{CRF}_{1}$ receptor mRNA (Chalmers et al, 1995). In isolated rats treated with candesartan, there was a small increase in septal $\mathrm{CRF}_{2}$ receptors. This finding may be of interest because activation of $\mathrm{CRF}_{2}$ receptors reverses anxiety-like behavior (Valdez et al, 2004) and $\mathrm{CRF}_{2}$ receptors have been proposed as regulators of the stress response (Risbrough et al, 2004).

In the cortex, CRF negatively modulates the activity of the $\mathrm{GABA}_{\mathrm{A}}$ complex, the main central inhibitory system (Takamatsu et al, 1991; Serra et al, 1999). The CRF and $\mathrm{GABA}_{\mathrm{A}}$ systems are tightly interconnected, and in the PVN, $\mathrm{GABA}_{\mathrm{A}}$ receptors colocalize with $\mathrm{CRF}$ neurons (Cullinan, 2000). A similar interaction is likely to occur in the cortex. The effect of $\mathrm{CRF}_{1}$ antagonists is similar to the effect of the benzodiazepines, the classical anxiolytic compounds, which stimulate central benzodiazepine sites, part of the inhibitory $\mathrm{GABA}_{\mathrm{A}}$ receptor complex (Nutt and Malizia, 2001; Zavala, 1997; Biggio et al, 1990). Stimulation of central benzodiazepine receptors increases the affinity of GABA for its binding site through positive allosteric effects, potentiating GABAergic transmission (Zavala, 1997). Isolation (present results) or exposure to inescapable stressors such as foot shock or forced swimming (Lippa et al, 1978; Weizman et al, 1989; Medina et al, 1983) decreased benzodiazepine receptor binding in the frontal cortex. In turn, decreased benzodiazepine binding decreases GABAergic transmission, and this leads to stress-induced anxiety (Nutt and Malizia, 2001). Our finding of decreased cortical benzodiazepine receptor binding during isolation is most likely associated 
with the stress-induced increase in cortical CRH release. By decreasing CRF release, $\mathrm{AT}_{1}$ receptor blockade would also reverse the stress-induced decrease in central benzodiazepine binding and restore the inhibitory influence of the $\mathrm{GABA}_{\mathrm{A}}$ complex during isolation.

In the elevated plus-maze, a test of anxiety-related behavior (Lister, 1987), pretreatment with candesartan increased the number of entries into the open arm of the maze and the time spent in the open arm, indicating a clear anxiolytic effect, similar to that found after peripheral administration of other $\mathrm{AT}_{1}$ receptor antagonists (Barnes et al, 1990; Kaiser et al, 1992) and to that of $\mathrm{CRF}_{1}$ receptor antagonists (Korte and De Boer, 2003; Millan et al, 2001).

Our results are not without clinical implications. Hyperactivity of the HPA axis and of CRF neurons regulating higher brain centers are confirmed findings in anxiety and in stress-related affective disorders (Bremner et al, 2000; Keck and Holsboer, 2001). We demonstrate here that inhibition of Ang II $\mathrm{AT}_{1}$ receptors is sufficient to block stress-induced changes in $\mathrm{CRF}_{1}$ receptors and to restore the inhibitory effect of the cortical $\mathrm{GABA}_{\mathrm{A}}$ system. Our hypothesis is that these effects explain the anxiolytic and anti-stress effects of centrally active $\mathrm{AT}_{1}$ receptor antagonists.

Our observations indicate that Ang II $\mathrm{AT}_{1}$ receptors are involved in higher regulatory mechanisms controlling the behavioral and cognitive responses to stress and anxiety. Antagonism of brain Ang II $\mathrm{AT}_{1}$ receptors could open a new lead in the treatment of anxiety and other stress-related psychiatric conditions such as depression and posttraumatic stress disorder.

\section{ACKNOWLEDGEMENTS}

We thank ASTRA Sweden for the supply of candesartan. This research was supported by the Intramural Research Program of the National Institute of Mental Health, NIH, DHHS.

\section{REFERENCES}

Aguilera G, Kiss A, Luo X (1995a). Increased expression of type 1 angiotensin II receptors in the hypothalamic paraventricular nucleus following stress and glucocorticoid administration. J Neuroendocrinol 7: 775-783.

Aguilera G, Young WS, Kiss A, Bathia A (1995b). Direct regulation of hypothalamic corticotropin-releasing-hormone neurons by angiotensin II. Neuroendocrinology 61: 437-444.

Anderson SM, Kant GJ, De Souza EB (1993). Effects of chronic stress on anterior pituitary and brain corticotropin-releasing factor receptors. Pharmacol Biochem Behav 44: 755-761.

Armando I, Carranza A, Nishimura Y, Hoe KL, Barontini M, Terrón JA et al (2001). Peripheral administration of an angiotensin II $\mathrm{AT}_{1}$ receptor antagonist decreases the hypothalamic-pituitaryadrenal response to stress. Endocrinology 142: 3880-3889.

Armando I, Terrón JA, Falcón-Neri A, Ito T, Häuser W, Inagami T et al (2002). Increased angiotensin $\mathrm{II}_{\mathrm{AT}_{1}}$ receptor expression in paraventricular nucleus and hypothalamic-pituitary-adrenal axis stimulation in $\mathrm{AT}_{2}$ receptor gene-disrupted mice. Neuroendocrinology 76: 137-147.

Barnes NM, Costall B, Kelly ME, Murphy DA, Naylor RJ (1990). Anxiolytic-like action of DuP753, a non-peptide angiotensin II receptor antagonist. Neuroreport 1: 20-21.
Berridge CW, Waterhouse BD (2003). The locus coeruleusnoradrenergic system: modulation of behavioral state and state-dependent cognitive processes. Brain Res Rev 42: 33-84.

Biggio G, Concas A, Corda MG, Giorgi O, Sanna E, Serra M (1990). GABAergic and dopaminergic transmission in the rat cerebral cortex: effects of stress, anxiolytic and anxiogenic drugs. Pharmacol Ther 48: 121-142.

Bittencourt JC, Sawchenko PE (2000). Do centrally administered neuropeptides access cognate receptors? An analysis in the central corticotropin-releasing factor system. J Neurosci 20: 1142-1156.

Bregonzio C, Armando I, Ando H, Jezova M, Baiardi G, Saavedra JM (2003). Angiotensin II $\mathrm{AT}_{1}$ receptor blockade prevents gastric ulcers during cold-restraint stress. Am J Physiol 285: G414-G423.

Bremner JD, Innis RB, Southwick SM, Staib L, Zoghbi S, Charney DS (2000). Decreased benzodiazepine receptor binding in prefrontal cortex in combat-related post traumatic stress disorder. Am J Psychiatry 157: 1120-1126.

Brunson KL, Grigoriadis DE, Lorang MT, Baram TZ (2002). Corticotropin-releasing hormone (CRH) downregulates the function of its receptor (CRF1) and induces CRF1 expression in hippocampal and cortical regions of the immature rat brain. Exp Neurol 176: 75-86.

Butler PD, Weiss JM, Stout JC, Nemeroff CB (1990). Corticotropin releasing factor produces fear-enhancing and behavioral activating effects following infusion into the locus coeruleus. J Neurosci 10: 176-183.

Carrasco GA, Van de Kar LD (2003). Neuroendocrine pharmacology of stress. Eur J Pharmacol 463: 235-272.

Castrén E, Saavedra JM (1988). Repeated stress increases the density of angiotensin II binding sites in the rat paraventricular nucleus and subfornical organ. Endocrinology 122: 370-372.

Chalmers DT, Lovenberg TW, De Souza EB (1995). Localization of novel corticotropin-releasing factor receptors $\left(\mathrm{CRF}_{2}\right)$ mRNA expression to specific subcortical nuclei in rat brain: comparison with $\mathrm{CRF}_{1}$ receptor mRNA expression. J Neurosci 15: 6340-6350.

Chappell PB, Smith MA, Kilts CD, Bissette G, Ritchie J, Anderson C et al (1986). Alterations in corticotropin-releasing factor like immunoreactivity in discrete rat brain regions after acute and chronic stress. J Neurosci 6: 2908-2914.

Cullinan WE (2000). GABA(A) receptor subunit expression within hypophysiotropic $\mathrm{CRH}$ neurons: a dual hybridization histochemical study. J Comp Neurol 419: 344-351.

De Gasparo M, Catt KJ, Inagami T, Wright JW, Unger T (2000). International union of pharmacology. XXIII. The angiotensin II receptors. Pharmacol Rev 52: 415-472.

Dunn AJ, Berridge CW (1990). Physiological and behavioral responses to corticotropin-releasing factor administration: is CRF a mediator of anxiety or stress responses? Brain Res Rev 15: 71-100.

Fernández-López A, Chinchetru MA, Fernández PC (1997). The autoradiographic perspective of central benzodiazepine receptors: a short review. Gen Pharmacol 29: 173-180.

Grima B, Lamouroux A, Blanot F, Biguet NF, Mallet J (1985). Complete coding sequence or rat tyrosine hydroxylase mRNA. Proc Natl Acad Sci USA 82: 617-621.

Guo DF, Uno S, Ishihata A, Nakamura N, Inagami T (1995). Identification of a cis-acting glucocorticoid responsive element in the rat angiotensin II type 1A promoter. Circ Res 77: 249-257.

Herman JP, Figueiredo H, Mueller NK, Ultich-Lai Y, Ostrander MM, Choi DC et al (2003). Central mechanisms of stress integration: hierarchical circuitry controlling hypothalamo-pituitary-adrenocortical responsiveness. Front Neuroendocrinol 24: 151-180.

Iredale PA, Terwilliger R, Widnell KL, Nestler EJ, Duman RS (1996). Differential regulation of corticotrophin-releasing factor 1 receptor expression by stress and agonist treatments in brain and cultured cells. Mol Pharmacol 50: 1103-1110.

Israel A, Strömberg C, Tsutsumi K, Garrido MDR, Torres M, Saavedra JM (1995). Angiotensin II receptor subtypes and 
phosphoinositide hydrolysis in rat adrenal medulla. Brain Res Bull 38: 441-446.

Jezova D, Ochedalski T, Kiss A, Aguilera G (1998). Brain angiotensin II modulates sympathoadrenal and hypothalamic pituitary adrenocortical activation during stress. J Neuroendocrinol 10: 67-72.

Jezova M, Armando I, Bregonzio C, Yu ZX, Qian S, Ferrans VJ et al (2003). Angiotensin II AT1 and AT2 receptors contribute to maintain basal adrenomedullary norepinephrine synthesis and tyrosine hydroxylase. Endocrinology 144: 2092-2101.

Jöhren O, Inagami T, Saavedra JM (1995). $\mathrm{AT}_{1 \mathrm{~A}}, \mathrm{AT}_{1 \mathrm{~B}}$, and $\mathrm{AT}_{2}$ angiotensin II receptor subtype gene expression in rat brain. Neuroreport 6: 2549-2551.

Kaiser FC, Palmer GC, Wallace AV, Carr RD, Fraser-Rae L, Hallam C (1992). Antianxiety properties of the angiotensin II antagonist, DUP 753, in the rat using the elevated plus-maze. Neuroreport 3: 922-924.

Keck ME, Holsboer F (2001). Hyperactivity of CRH neuronal circuits as a target for therapeutic interventions in affective disorders. Peptides 22: 835-844.

Koob GF (1999). Corticotropin releasing factor, norepinephrine and stress. Biol Psychiatry 46: 1167-1180.

Korte MS, De Boer SF (2003). A robust animal model of state anxiety: fear potentiated behavior in the elevated plus-maze. Eur J Pharmacol 463: 163-175.

Lenkei Z, Palkovits M, Corvol P, Llorens-Cortes C (1998). Distribution of angiotensin type-1 receptor messenger RNA expression in the adult rat brain. Neuroscience 82: 827-841.

Leong DS, Terrón JA, Falcón-Neri A, Armando I, Ito T, Jöhren O et al (2002). Restraint stress modulates brain, pituitary and adrenal expression of angiotensin II $\mathrm{AT}_{1 \mathrm{~A}}, \mathrm{AT}_{1 \mathrm{~B}}$ and $\mathrm{AT}_{2}$ receptors. Neuroendocrinology 75: 227-240.

Lippa AS, Klepner CA, Yunger L, Sano MC, Smith WV, Beer B (1978). Relationship between benzodiazepine receptors and experimental anxiety in rats. Pharmacol Biochem Behav 9: 853-856.

Lister RG (1987). The use of a plus-maze to measure anxiety in the mouse. Psychopharmacology (Berl) 92: 180-185.

McCarthy JR, Heindrichs SC, Grigoriadis DE (1999). Recent advances with the CRF1 receptor: design of small molecule inhibitors, receptor subtypes and clinical indications. Curr Pharm Des 5: 289-315.

Medina JH, Novas ML, Wolfman CN, Levi de Stein M, De Robertis E (1983). Benzodiazepine receptors in rat cerebral cortex and hippocampus undergo rapid and reversible changes after acute stress. Neuroscience 9: 331-335.

Menzaghi F, Howard RL, Heinrichs SC, Vale W, Rivier J, Koob GF (1994). Characterization of a novel and potent corticotropinreleasing factor antagonist in rats. J Pharmacol Exp Ther 269: 564-572.

Millan MJ, Brocco M, Gobert A, Dorey G, Casara P, Dekeyne A (2001). Anxiolytic properties of the selective, non-peptidergic CRF1 antagonists, CP154526 and DMP695: a comparison to other classes of anxiolytic agent. Neuropsychopharmacology 25: 585-600.

Miller JA, Zahniser NR (1987). The use of ${ }^{14} \mathrm{C}$-labeled tissue paste standards for the calibration of ${ }^{125}$ I-labeled ligands in quantitative autoradiography. Neurosci Lett 81: 345-350.

Montgomery KC (1955). The relation between fear induced by novel stimulation and exploratory behavior. J Comp Psychol 48: 254-260.

Nazarali AJ, Gutkind JS, Saavedra JM (1989). Calibration of [ $\left.{ }^{125} \mathrm{I}\right]-$ polymer standards with $\left[{ }^{125} \mathrm{I}\right]$ brain paste standards for use in quantitative receptors autoradiography. J Neurosci Methods 30: 247-253.

Negro M, Fernández-López A, Calvo P (1995). Autoradiographical study of types 1 and 2 of benzodiazepine receptors in rat brain alter chronic ethanol treatment and its withdrawal. Neuropharmacology 34: 1177-1182.
Nishimura Y, Ito T, Hoe K-L, Saavedra JM (2000). Chronic peripheral administration of the angiotensin II $\mathrm{AT}_{1}$ receptor antagonist candesartan blocks brain $\mathrm{AT}_{1}$ receptors. Brain Res 871: 29-38.

Nutt DJ, Malizia AL (2001). New insights into the role of the GABA(A)-benzodiazepine receptor in psychiatric disorder. $\mathrm{Br} \mathrm{J}$ Psychiatry 179: 390-394.

Okuyama S, Sakagawa T, Chaki S, Imagawa Y, Ichiki T, Inagami T (1999). Anxiety-like behavior in mice lacking the angiotensin II type-2 receptor. Brain Res 821: 150-159.

Oldfield BJ, Davern PJ, Giles ME, Allen AM, Badoer E, McKinley MJ (2001). Efferent neural projections of angiotensin receptor (AT1) expressing neurons in the hypothalamic paraventricular nucleus of the rat. J Neuroendocrinol 13: 139-146.

Orchinik M, Carroll SS, Li HY, McEwen BS, Weiland NG (2001). Heterogeneity of hippocampal GABA(A) receptors: regulation by corticosterone. J Neurosci 21: 330-339.

Paxinos G, Watson C (1986). The Rat Brain in Stereotaxic Coordinates. Academic Press: New York.

Peng JF, Phillips MI (2001). Opposite regulation of brain angiotensin type 1 and type 2 receptors in cold-induced hypertension. Regul Peptides 97: 91-102.

Phillips MI (1997). Functions of angiotensin in the central nervous system. Annu Rev Physiol 3: 103-126.

Primus RJ, Yevich E, Baltazar C, Gallager DW (1997). Autoradiographic localization of CRF1 and CRF2 binding sites in adult rat brain. Neuropsychopharmacology 17: 308-316.

Risbrough VB, Hauger RL, Roberts AL, Vale WW, Geyer MA (2004). Corticotropin-releasing factor receptors CRF1 and CRF2 exert both additive and opposing influences on defensive startle behavior. I Neurosci 21: 6545-6552.

Rodgers RJ, Johnson NJ (1998). Behaviorally selective effects of neuroactive steroids on plus-maze anxiety in mice. Pharmacol Biochem Behav 59: 221-232.

Rodriguez de Fonseca F, Rubio P, Menzaghi F, Merlo Pich E, Rivier J, Koob GF et al (1996). Corticotropin-releasing factor (CRF) antagonist [D-Phe12,Nle21,38, Calpha MeLeu37] CRF attenuates the actions of the highly potent cannabinoid receptor agonist HU-210 on defensive withdrawal behavior in rats. J Pharmacol Exp Ther 276: 56-64.

Rominger DH, Rominger CM, Fitzgerald LW, Grzanna R, Largent BL, Zaczek R (1998). Characterization of $\left[{ }^{125} \mathrm{I}\right]$ Sauvagine binding to $\mathrm{CRH} 2$ receptors: membrane homogenate and autoradiographic studies. J Pharmacol Exp Ther 286: 459-468.

Saavedra JM (1992). Brain and pituitary angiotensin. Endocr Rev 18: $21-53$

Saavedra JM (1999). Emerging features of brain angiotensin receptors. Regul Peptides 85: 31-45.

Sánchez MM, Young LJ, Plotsky PM, Insel TR (1999). Autoradiographic and in situ hybridization localization of corticotropinreleasing factor 1 and 2 receptors in nonhuman primate brain. J Comp Neurol 408: 365-377.

Schulz DM, Mansbach RS, Sprouse J, Braselton JP, Collins J, Corman $\mathrm{M}$ et al (1996). CP-154526: a potent and selective antagonist of corticotropin releasing factor receptors. Proc Natl Acad Sci USA 93: 10477-10482.

Seltzer A, Bregonzio C, Armando I, Baiardi G, Saavedra JM (2004). Oral administration of an $\mathrm{AT}_{1}$ receptor antagonist prevents the central effects of angiotensin II in spontaneously hypertensive rats. Brain Res 1028: 9-18.

Serra M, Concas A, Mostallino MC, Chessa MF, Stomati M, Petraglia F et al (1999). Antagonism by pivagabine of stress-induced changes in GABAA receptor function and corticotropin-releasing factor concentrations in rat brain. Psychoneuroendocrinology 24: 269-284.

Shimizu N, Nakane H, Hori T, Hayashi Y (1994). CRF receptor antagonist attenuates stress-induced noradrenaline release in the medial prefrontal cortex of rats. Brain Res 654: 145-148. 
Smith GW, Aubry JM, Dellu F, Contarino A, Bilezikjian LM, Gold LH et al (1998). Corticotropin releasing factor receptor 1-deficient mice display decreased anxiety, impaired stress response, and aberrant neuroendocrine development. Neuron 20: 1093-1102.

Sumitomo T, Suda T, Nakano Y, Tozawa F, Yamada M, Demura H (1991). Angiotensin II increases the corticotropin-releasing factor messenger ribonucleic acid levels in the rat hypothalamus. Endocrinology 128: 2248-2252.

Szafarczyk A, Feuvrier E, Siaud P, Rondouin G, Lacoste M, Gaillet $S$ et al (1995). Removal of adrenal steroids from the medium reverses the stimulating effects of catecholamines on corticotropin-releasing hormone neurons in organotypic cultures. Neuroendocrinology 61: 517-524.

Takamatsu Y, Yamamoto H, Ogunremi OO, Matsuzaki I, Moroji T (1991). The effects of corticotropin-releasing hormone on peptidergic neurons in the rat forebrain. Neuropeptides 20: 255-265.

Tsutsumi K, Saavedra JM (1991a). Characterization and development of angiotensin II receptor subtypes $\left(\mathrm{AT}_{1}\right.$ and $\left.\mathrm{AT}_{2}\right)$ in rat brain. Am J Physiol 26: 209-216.

Tsutsumi K, Saavedra JM (1991b). Angiotensin II receptor subtypes in median eminence and basal forebrain areas involved in the regulation of pituitary function. Endocrinology 129: 3001-3008.

Valdez GR, Sabino V, Koob GF (2004). Increased anxiety-like behavior and ethanol self-administration in dependent rats: reversal via corticotropin-releasing factor-2 receptor activation. Alcohol Clin Exp Res 28: 865-972.

Van Pett K, Viau V, Bittencourt JC, Chan RK, Li HY, Arias C et al (2000). Distribution of mRNAs encoding CRF receptors in brain and pituitary of rat and mouse. J Comp Neurol 428: 191-212.

Webster EL, Lewis DB, Torpy DJ, Zachman EK, Rice KC, Chrousos GP (1996). In vivo and in vitro characterization of antalarmin, a nonpeptide corticotropin-releasing hormone (CRH) receptor antagonist: suppression of pituitary ACTH release and peripheral inflammation. Endocrinology 137: 5747-5750.

Weizman R, Weizman A, Kook KA, Vocci F, Deutsch SI, Paul SM (1989). Repeated swim stress alters brain benzodiazepine receptors measured in vivo. J Pharmacol Exp Ther 249: 701-707.

Whitnall MH (1993). Regulation of the hypothalamic corticotropin-releasing hormone neurosecretory system. Prog Neurobiol 40: $573-629$.

Wisden W, Morris BJ (1994). In situ hybridization with synthetic oligonucleotide probes. In: Wisden W, Morris BJ (eds). In Situ Hybridization Protocols for the Brain. Academic Press: San Diego. pp 9-34.

Xang G, Xi ZX, Wan Y, Wang H, Bi G (1993). Changes in circulating and tissue angiotensin II during acute and chronic stress. Biol Signals 2: 166-172.

Yang G, Wan Y, Zhu Y (1996). Angiotensin II-an important stress hormone. Biol Signals 5: 1-8.

Zavala F (1997). Benzodiazepines, anxiety and immunity. Pharmacol Ther 75: 199-216. 